\title{
HILGARDIA
}

A Journal of Agricultural Science Published by the California Agricultural Experiment Station

\section{INHERITANCE OF SOME SEED-COAT COLORS AND PATTERNS IN LIMA BEANS}

\author{
R. W. ALLARD
}


FIVE GENE PAIRS governing seed-coat color in lima beans and their relationships to some hypocotyl and flower-color genes are described. These genes are:

Cc-governs red vs. white seed-coat color; acts as a basic color factor in the production of colored hypocotyls, flowers, and other seed-coat colors.

$\mathrm{Rr}$-produces dark-red seed-coat color and red hypocotyl color in the presence of $C_{-}$.

Pp-produces purple seed-coat, purple hypocotyl, and purple flower color in the presence of $C_{\text {. }}$.

C_R_P_-produces black seed-coat, red-purple hypocotyl, and purple flower color.

Ss-SS changes red, dark-red, purple, or black seed-coat color to red/buff, dark-red/buff, purple/buff, or black/buff, respectively. The heterozygote, Ss, produces a diffuse-type mottling, which can be distinguished from SS (restricted mottling) or ss (no mottling).

Srsr-modifies the background color associated with the mottle allele S; Sr_produces buff background color and srsr red background color. This gene pair is expressed only in the presence of SS or Ss. In mottled genotypes, the effect of the $R$ and $P$ alleles is largely confined to the mottled portions of the seed coat. However, individuals with black mottling generally have slightly darker background colors than individuals with red, dark-red, or purple mottles.

Variability among individuals in all of the color groups studied indicates the existence of some seed-coat color genes less effective than the ones described. 


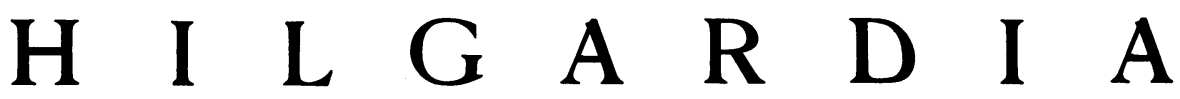

A Journal of Agricultural Science Published by

the California Agricultural Experiment Station

\section{INHERITANCE OF SOME SEED-COAT COLORS AND PATTERNS IN LIMA BEANS ${ }^{1}$}

\section{R. W. ALLARD ${ }^{2}$}

A GREAT DIVERSITY OF SEED-COAT COLORS AND PATTERNS occurs in the lima bean species, Phaseolus lunatus L. ; among the most common colors are white, red, purple, and black, while the most common patterns are self-colored and mottled. The Mendelian basis of the inheritance of these colors is imperfectly known, the only report in the literature being that of Rhind (1933), who described two color genes and one pattern gene. According to Rhind, the gene pair $R r$ governs rose $v s$. white color, and the dominant allele of the gene pair $P p$ is an intensifier which darkens the rose color of $R$ to purple, but is inactive in the presence of $r r$. Rhind reported that the gene pair $S s$ is incompletely dominant, $S s$ producing light (restricted) speckling, $S s$ heavy (diffuse) speckling, and ss self-color.

The investigations of seed-coat color reported here were conducted at Davis, California, during the period 1947-1952. These studies have contributed additional evidence regarding the inheritance of seed-coat color and have also established the relationships of the seed-coat color genes to some genes governing hypocotyl and flower color (Allard, 1952).

\section{MATERIALS AND METHODS}

The four parents with white seed coats used in these studies are the widely grown commercial varieties Henderson, Green-Seeded Henderson, Wilbur, and Westan. The colored parents are all unnamed strains maintained in the University of California lima-bean collection. The seed-coat colors and patterns are given in table 1 . Color designations follow the Munsell system. ${ }^{3}$

In table 1 and thereafter, a single color designation indicates that the seed coat is self-colored. Mottled seed coats are indicated by a dual color designation. As an example, red/buff indicates red mottling on a buff background color. The two types of mottling observed, restricted and diffuse (fig. 1), are distinguished by underscoring. Thus red/buff indicates restricted red mottling on a buff background, and red/buff indicates diffuse mottling involving the same colors.

${ }^{1}$ Received for publication December 17, 1952.

${ }^{2}$ Associate Professor of Agronomy, Davis.

${ }^{8}$ Munsell Book of Color. Munsell Color Co., Baltimore, Md. 1942. 
TABLE 1

SEED-COAT COLORS OF PARENTAL VARIETIES OR STRAINS, ACCORDING TO THE MUNSELL SYSTEM

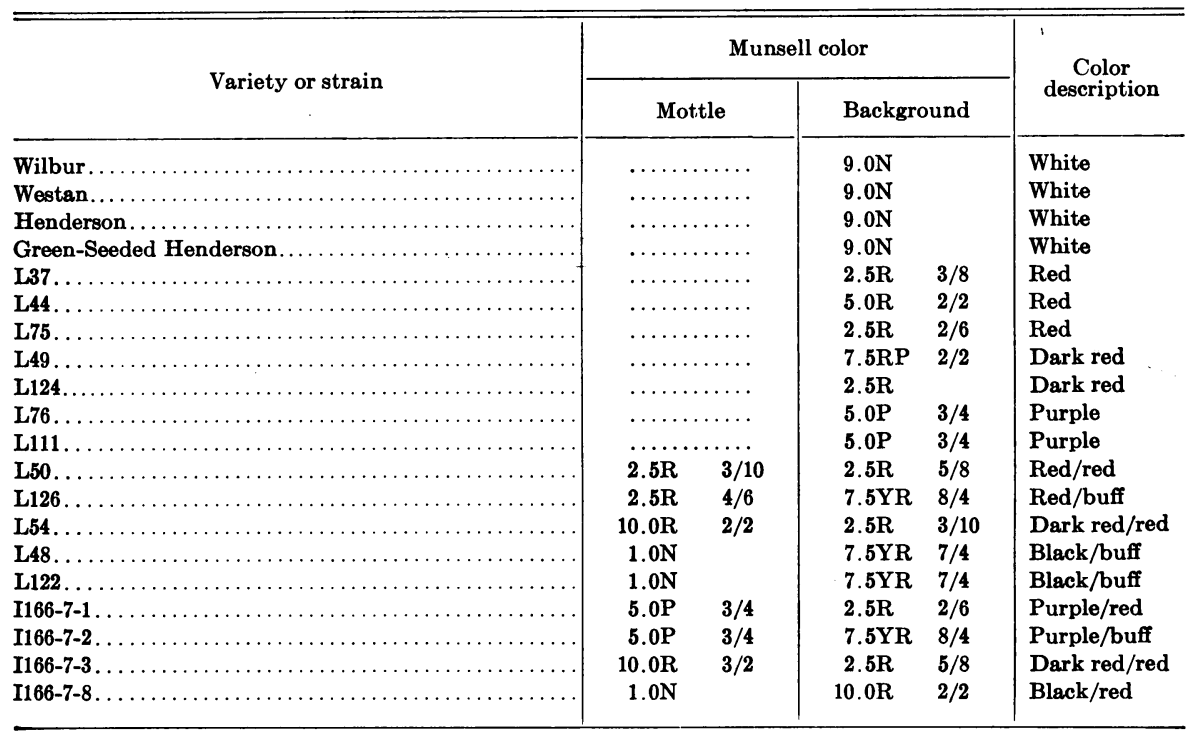
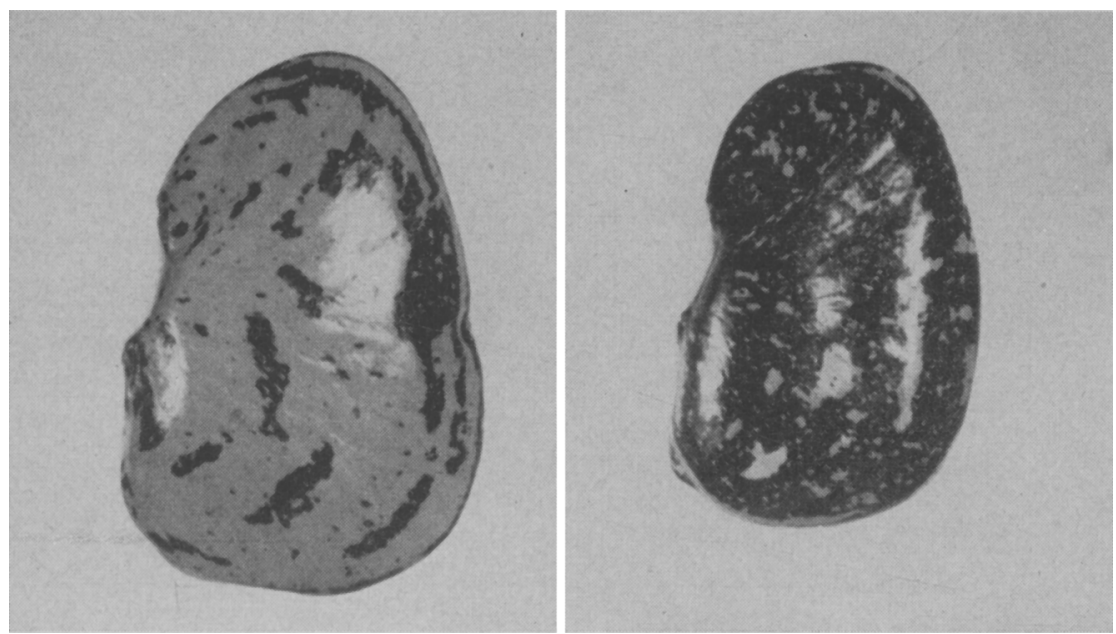

Fig. 1. Left: Restricted mottling produced by the genotype SS. Right: Diffuse mottling produced by the genotype $S s$.

When $\mathrm{F}_{3}$ or $\mathrm{F}_{4}$ progenies were grown to identify the genotype of $\mathrm{F}_{2}$ or $\mathrm{F}_{3}$ plants, minimum progeny sizes necessary to distinguish between the expected ratios at odds 99:1 were calculated in order that the appropriate number of seeds might be planted in each progeny. In certain progenies inadequate numbers were obtained to permit the positive identification of genotypes, and an additional planting the following season was necessary. 


\section{EXPERIMENTAL RESULTS \\ Hybrids of White $\times$ Red}

In three hybrids (table 2 ) between parents with white and red seed coats, the $\mathrm{F}_{1}$ seed-coat color in each case was red. The ratios observed in $\mathrm{F}_{2}$ indicate that a single gene pair governs this color difference (table 2). Additional

TABLE 2

OBSERVED SEGREGATION AND GOODNESS OF FIT TO A RATIO OF 3 RED:1 WHITE IN THE $\mathrm{F}_{2}$ OF HYBRIDS BETWEEN PARENTS WITH RED AND WHITE SEED COATS

\begin{tabular}{|c|c|c|c|c|}
\hline Hybrid & $\begin{array}{c}\text { Red, } \\
\text { number }\end{array}$ & $\begin{array}{l}\text { White, } \\
\text { number }\end{array}$ & $x^{2}$ & $\begin{array}{l}\text { Probability } \\
\text { exceeds }\end{array}$ \\
\hline 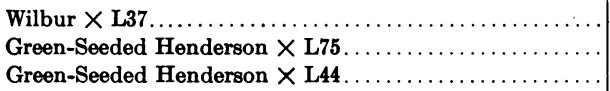 & $\begin{array}{l}342 \\
171 \\
168\end{array}$ & $\begin{array}{l}99 \\
75 \\
69\end{array}$ & $\begin{array}{l}1.53 \\
3.95 \\
2.13\end{array}$ & $\begin{array}{l}0.20 \\
0.02 \\
0.10\end{array}$ \\
\hline
\end{tabular}

TABLE 3

OBSERVED SEGREGATION AND GOODNESS OF FIT TO A RATIO OF 9 DARK RED:3 RED:4 WHITE IN THE $F_{2}$ OF HYBRIDS BETWEEN PARENTS WITH DARK-RED AND WHITE SEED COATS

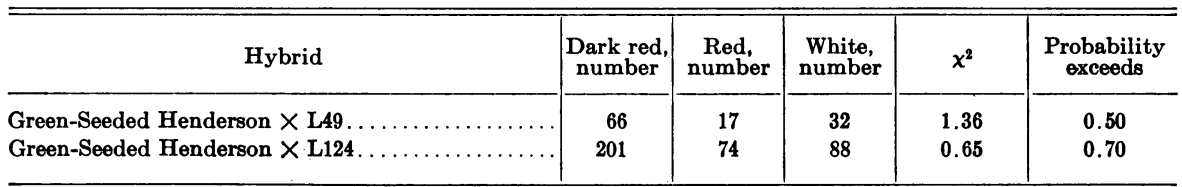

evidence was obtained from a small $\mathrm{F}_{3}$ of the hybrid Green-Seeded Henderson $\times$ L75. Among 30 families derived from red-seeded $F_{2}$ parents, 12 were homozygous for red seed-coat color, and 18 segregated approximately 3 red:1 white-an acceptable fit to the expected 1:2 ratio. Ten $\mathrm{F}_{2}$ plants with white seed coats produced only white-seeded $\mathrm{F}_{3}$ progeny.

\section{Hybrids of Dark Red $\times$ White}

The seed-coat of the $F_{1}$ in the two hybrids studied (table 3 ) was indistinguishable from that of the colored parents. In the $\mathrm{F}_{2}$ generation, three seed-coat colors occurred, the parental colors and red. Although there was considerable variation in the hue, chroma, and value within the two colored classes, little difficulty was encountered in distinguishing between the darkred and the red groups. The proportion of dark red:red:white was 9:3:4, indicating that the parents differ in two gene pairs. One of these gene pairs apparently governs red $v s$. white seed-coat color, and the other intensifies the red color to dark red but is not expressed except in the presence of at least one dominant allele of the red-white pair.

A total of $89 \mathrm{~F}_{3}$ families from the hybrid Green-Seeded Henderson $\times \mathrm{L} 124$ were grown to test this hypothesis. Among the $20 \mathrm{~F}_{3}$ progenies derived from 
$\mathrm{F}_{2}$ parents with red seed coats, 7 were homozygous for red seed-coat color, and 13 families segregated approximately 3 red:1 white. This is a good fit to the $1: 2$ ratio expected. The $1: 2: 2: 4$ ratio expected among the $F_{3}$ progeny of $\mathrm{F}_{2}$ plants with dark-red seed coats was also realized (table 4 ). Ten $\mathrm{F}_{2}$ plants with white seed coats produced only white-seeded progeny. Thus $\mathrm{F}_{3}$ data confirm the Mendelian scheme deduced from the $\mathrm{F}_{2}$ segregation.

The hypocotyl color of both of the dark-red-seeded parents, L49 and L124, is red, while that of the Green-Seeded Henderson parent is green. It is known that red hypocotyl color in lima beans is produced by the coopperation of the dominant alleles of the gene pairs $C c$ and $R r$ (Allard, 1952), resulting in ratios of 9 red: 7 green in $F_{2}$. In the $F_{2}$ of the present hybrids, the ratios of plants with red hypocotyls to plants with green hypocotyls were 146:139 for the hybrid Green-Seeded Henderson $\times$ L49 and 150:141 for the hybrid of

TABLE 4

OBSERVED SEGREGATION AND GOODNESS OF FIT TO A RATIO OF 1:2:2:4 AMONG THE PROGENIES OF $F_{2}$ INDIVIDUALS WITH DARK-RED SEED COATS

\begin{tabular}{c|c|c|c|c|c|c}
\hline \hline Hybrid & $\begin{array}{c}\text { Homo. } \\
\text { dark red, } \\
\text { number }\end{array}$ & $\begin{array}{c}\text { 3 Dark } \\
\text { red : 1 red, } \\
\text { number }\end{array}$ & $\begin{array}{c}\text { 3 Dark } \\
\text { red : 1 } \\
\text { white, } \\
\text { number }\end{array}$ & $\begin{array}{c}9: 3: 4, \\
\text { number }\end{array}$ & $x^{2}$ & $\begin{array}{c}\text { Probability } \\
\text { exceeds }\end{array}$ \\
\hline E.T. $\times$ L124............................... & 2 & 12 & 11 & 34 & 5.908 & 0.10 \\
\hline
\end{tabular}

Green-Seeded Henderson $\times$ L124. These are acceptable fits to a 9:7 ratio. Because hypocotyl color can be classified accurately only in seedling stages, and seed-coat color only at maturity, it was necessary to mark seedling plants to establish correlations between hypocotyl and seed-coat colors. When this was done it was found that plants with red hypocotyls invariably had dark-red seed coats and that green hypocotyl color was associated with red or white seed-coat color. It is apparent that the basic color factor and the redpigmentation gene pairs involved in the production of red hypocotyl color are identical with the red and dark-red seed-coat color genes, respectively, of the present hybrids. Using the symbols applied to the hypocotyl-color genes (Allard, 1952), the colored parents, L49 and L124, are genotypically CCRR, and the Green-Seeded Henderson parent is genotypically $c c r r$. It is suggested that $C c$ be adopted as the symbol for the basic color factor, despite the priority of Rhind's symbol, because it is more descriptive of the action of this gene.

\section{Hybrids of White $\times$ Purple}

The seed-coat color of the four $\mathrm{F}_{1}$ hybrids studied (table 5) was indistinguishable from that of the purple parents. In the $\mathrm{F}_{2}$ generation three seed-coat colors-purple, red, and white-occurred in a ratio of $9: 3: 4$ (table $5)$. Although there was considerable variability within the two colored classes, the discontinuity between the two groups was clearly demarked. Among the $\mathrm{F}_{3}$ progenies of $20 \mathrm{~F}_{2}$ plants with red seed coats, six were homozygous for red, and 14 segregated approximately 3 red:1 white. A 1:2:2:4 ratio was observed among $\mathrm{F}_{3}$ progenies of purple-seeded $\mathrm{F}_{2}$ plants (table 6 ). 
By marking $\mathrm{F}_{2}$ plants in seedling stages it was established that plants with purple hypocotyls invariably had purple flowers and purple seed coats, whereas plants with green hypocotyls had white flowers and either red or white seed coats. Purple pigmentation of the hypocotyl, flowers, and seed coat thus results from manifold effects of the same purple-pigmentation gene.

TABLE 5

OBSERVED SEGREGATION AND GOODNESS OF FIT TO A RATIO OF 9 PURPLE:3 RED:4 WHITE IN THE $F_{2}$ OF HYBRIDS BETWEEN PARENTS WITH PURPLE AND WHITE SEED COATS

\begin{tabular}{|c|c|c|c|c|c|}
\hline Hybrid & $\begin{array}{l}\text { Purple, } \\
\text { number }\end{array}$ & $\begin{array}{c}\text { Red, } \\
\text { number }\end{array}$ & $\begin{array}{l}\text { White, } \\
\text { number }\end{array}$ & $x^{2}$ & $\begin{array}{l}\text { Probability } \\
\text { exceeds }\end{array}$ \\
\hline Wilbur $\times$ L76 $\ldots \ldots \ldots \ldots$ & 223 & 60 & 94 & 2.14 & $\mathbf{0 . 3 0}$ \\
\hline Green-Seeded Henderson $\times$ L76 $\ldots \ldots \ldots$ & 187 & 74 & 99 & 2.71 & 0.20 \\
\hline Westan $\times$ L76 $\ldots \ldots \ldots \ldots \ldots \ldots \ldots$ & 132 & 52 & 79 & 5.03 & 0.05 \\
\hline Green-Seeded Henderson $\times$ L111 $\ldots \ldots \ldots \ldots \ldots$ & 73 & 21 & 43 & 3.30 & 0.10 \\
\hline
\end{tabular}

TABLE 6

OBSERVED SEGREGATION AND GOODNESS OF FIT TO A RATIO OF 1:2:2:4 AMONG THE PROGENIES OF $\mathrm{F}_{2}$ INDIVIDUALS WITH PURPLE SEED COATS

\begin{tabular}{|c|c|c|c|c|c|c|}
\hline Hybrid & $\begin{array}{c}\text { Homo. } \\
\text { purple, } \\
\text { number }\end{array}$ & 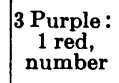 & $\begin{array}{l}3 \text { Purple: } \\
1 \text { white, } \\
\text { number }\end{array}$ & $\begin{array}{l}9: 3: 4, \\
\text { number }\end{array}$ & $x^{2}$ & $\begin{array}{l}\text { Probability } \\
\text { exceeds }\end{array}$ \\
\hline$\ldots \ldots \ldots \ldots \ldots \ldots \ldots$ & 4 & 11 & 16 & 20 & 2.735 & 0.30 \\
\hline
\end{tabular}

TABLE 7

OBSERVED SEGREGATION AND GOODNESS OF FIT TO A RATIO OF 3:6:3:4 IN THE $F_{2}$ OF HYBRIDS BETWEEN PARENTS WITH RED/RED AND WITH WHITE SEED COATS

\begin{tabular}{c|c|c|c|c|c|c}
\hline \hline Hybrid & $\begin{array}{c}\text { Red/red, } \\
\text { number }\end{array}$ & $\frac{\text { Red/red, }}{\text { number }}$ & $\begin{array}{c}\text { Red, } \\
\text { number }\end{array}$ & $\begin{array}{c}\text { White, } \\
\text { number }\end{array}$ & $x^{2}$ & $\begin{array}{c}\text { Probability } \\
\text { exceeds }\end{array}$ \\
\hline Green-Seeded Henderson $\times$ L50......... & 38 & 68 & 42 & 46 & 1.38 & 0.70 \\
\hline
\end{tabular}

This gene is identical with the purple-hypocotyl gene described by Allard (1952) and is apparently the same as the intensifier gene of Rhind (1933). The genetic formula for the purple parents in these hybrids is thus $C C P P$, and the formula for the white-seeded parents is ccpp.

\section{Hybrid of White $\times$ Red/Red}

A single hybrid of this type was studied (table 7 ). It was expected that the red/red parent would carry the basic color factor $C C$ and the mottling (speckle) gene, SS, of Rhind (1933), and Green-Seeded Henderson is known from the hybrids previously reported to be genotypically ccss. These predictions were confirmed when the seed-coat color and pattern of the $\mathrm{F}_{1}$ hybrid was red/red and when a good fit to a 3:6:3:4 ratio was obtained in the $F_{2}$ (table 7). 


\section{Hybrid of White $\times$ Red/Buff}

The $\mathrm{F}_{1}$ hybrid of Green-Seeded Henderson $\times$ L126 had seed coats red/buff in color and pattern. It was possible to identify six classes in the $\mathrm{F}_{2}$, as shown in table 8 . The $9: 18: 3: 6: 12: 16$ ratio observed would be expected if the white parent were genotypically ccsssrsr and the colored parent $C C S S S r S r$, where the Srsr alleles govern the background color, $S r_{-}$producing buff background and srsr red background color in the presence of $S_{-}$but being inoperative in the presence of $s s$.

TABLE 8

OBSERVED SEGREGATION AND GOODNESS OF FIT TO A RATIO OF $9: 18: 3: 6: 12: 16$ IN THE $F_{2}$ OF HYBRIDS BETWEEN PARENTS WITH. RED/BUFF AND WITH WHITE SEED COATS (GREEN-SEEDED HENDERSON $\times$ L126)

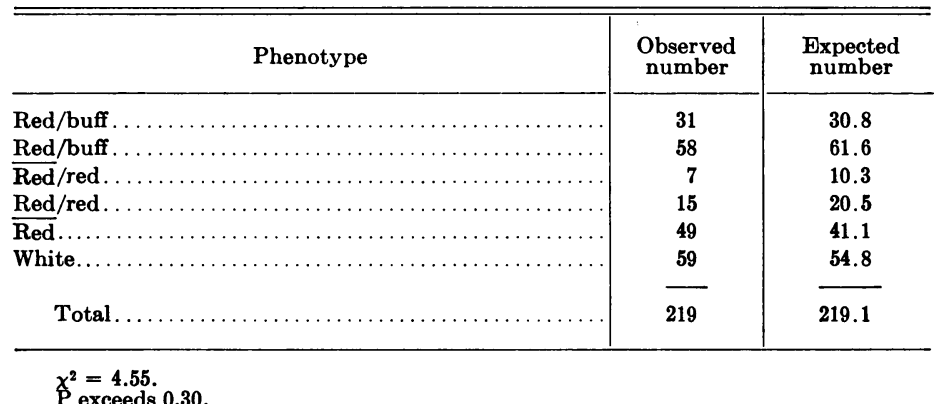

A total of 45 colored $\mathrm{F}_{3}$ families were grown to check this hypothesis. It was possible to study the segregation of the postulated $S r s r$ gene pair in 39 families with mottled seed coats. Six families derived from $\mathrm{F}_{2}$ plants with red background color produced only parental types with respect to background color. Of the $33 \mathrm{~F}_{3}$ families derived from $\mathrm{F}_{2}$ plants with buff background color, 10 were homozygous for this type, and 23 segregated approximately 3 buff background:1 red background. These results indicate monogenic control of background color.

Six of the 45 families were derived from self-colored $\mathrm{F}_{2}$ plants. They proved to be homozygous for self color and, were judged to be genotypically ss. Similarly, eight families derived from parents with restricted mottling bred true for this characteristic, and were genotypically SS. The remaining 31 families were derived from parents with seed coats characterized by diffuse mottling; all 31 produced restricted mottled plants, diffuse mottled plants, and self-colored plants in a ratio of approximately $1: 2: 1$. In none of the self-colored individuals was there any indication of modification of the seedcoat color by action of the Srsr gene pair.

Among the $45 \mathrm{~F}_{3}$ families, 18 were homozygous colored, and 27 segregated approximately 3 colored: 1 white. This represents a good fit to the expected segregation at the $C c$ locus. Both $\mathrm{F}_{2}$ and $\mathrm{F}_{3}$ segregations thus support the genetic formulas for the parents predicted from the parental seed-coat colors. 
The symbol Srsr was chosen to indicate that this gene pair governs the background color associated with the $S s$ locus, modifying the buff background color to red.

\section{Hybrid of White $\times$ Dark Red/Red}

It was deduced on the basis of the genes reported above that the $F_{1}$ of the hybrid between Green-Seeded Henderson and L54 should be genotypically CcRrSssrsr. All of the classes expected on the basis of this Mendelian proposition occurred in the frequencies expected in the $\mathrm{F}_{2}$ generation (table 9). The segregation for hypocotyl color was determined in seedling stage, 136 red

TABLE 9

OBSERVED SEGREGATION AND GOODNESS OF FIT TO A RATIO OF $9: 18: 9: 3: 6: 3: 16$ IN $F_{2}$ OF THE HYBRID GREEN-SEEDED HENDERSON $\times$ L54 (WHITE $\times$ DARK RED/RED)

\begin{tabular}{|c|c|c|}
\hline Phenotype & $\begin{array}{c}\text { Observed } \\
\text { number }\end{array}$ & $\begin{array}{l}\text { Expected } \\
\text { number }\end{array}$ \\
\hline 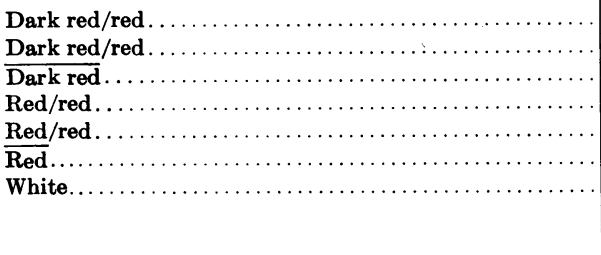 & $\begin{array}{r}33 \\
69 \\
30 \\
7 \\
26 \\
10 \\
62 \\
237\end{array}$ & $\begin{array}{l}33.3 \\
66.7 \\
33.3 \\
11.1 \\
22.2 \\
11.1 \\
59.3 \\
237.0\end{array}$ \\
\hline
\end{tabular}

$\chi^{2}=2.82$
P exceeds 0.80 .

and 115 green individuals being observed, an acceptable fit to a 9:7 ratio. Complete correlation was found between red hypocotyl and dark-red seedcoat colors, and between green hypocotyl and red or white seed-coat colors.

\section{Hybrid of White $\times$ Black/Buff}

One hybrid of this type, Westan $\times$ L48, was studied. $F_{1}$ hybrid plants had red-purple hypocotyls and black/buff seed coats. The genetic control of hypocotyl color in this hybrid is known to be as follows (Allard, 1952): $C \_R_{\perp} P_{-}-$red purple ; $C \_R_{-} p p-$ red ; $C \_r r P \_-$purple ; $c c_{-}$or $C_{-} r r p p$ - green. By marking seedling $\mathrm{F}_{2}$ plants of various hypocotyl colors, it was established that red-purple hypocotyl color was associated with black or black/buff seed coats, red hypocotyl color with dark-red or dark-red/buff seed-coat color, purple hypocotyl color with purple or purple/buff seed-coat color, and green hypocotyl color with red, red/buff, or white seed-coat color. This suggested that the genotypes of the parents are CCRRPPSS (L48) and ccrppss (Westan).

The segregation for seed-coat color in $\mathrm{F}_{2}$ supports the above Mendelian scheme (table 10). It should be noted that classification for the mottle gene, $S s$, was on the basis of mottled $v s$. nonmottled only. This restricted classification was necessary because only single seeds were harvested from the ma- 
jority of the $\mathrm{F}_{2}$ plants, and the variability in the extent of mottling between seeds on some plants was sufficiently great so that a single seed did not allow accurate separation of $S S$ from $S s$ individuals.

In order to establish certainly that four genes govern the differences between the parents, selected $\mathrm{F}_{3}$ and $\mathrm{F}_{4}$ progenies were grown. Since 55 different $\mathrm{F}_{2}$ genotypes should be distinguishable from $\mathrm{F}_{3}$ progeny tests, the number of progenies required to determine the statistical relationships between progenies was impractically large. Hence only a limited number of progenies representing the various seed-coat colors and patterns were selected for

TABLE 10

OBSERVED SEGREGATION AND GOODNESS OF FIT TO A RATIO OF $81: 27: 27: 9: 27: 9: 9: 3: 64$ IN THE $F_{2}$ OF THE HYBRID WESTAN $\times \mathrm{L} 48$

\begin{tabular}{|c|c|c|}
\hline Phenotype & $\begin{array}{c}\text { Observed } \\
\text { number }\end{array}$ & $\begin{array}{c}\text { Expected } \\
\text { number }\end{array}$ \\
\hline Black/buff. & 302 & 298.7 \\
\hline Black...... & 78 & 99.6 \\
\hline .Dark red/buff . . . & 109 & 99.6 \\
\hline Dark red......... & 36 & 33.2 \\
\hline Purple/buff.... & 101 & 99.6 \\
\hline 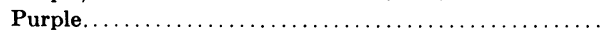 & 27 & 33.2 \\
\hline Red/buff $\ldots \ldots \ldots \ldots \ldots \ldots \ldots \ldots \ldots \ldots \ldots \ldots$ & 37 & 33.2 \\
\hline 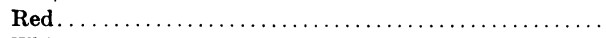 & 15 & 11.1 \\
\hline 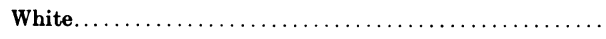 & 239 & 236.0 \\
\hline Total. . & 944 & 944.2 \\
\hline
\end{tabular}

further tests. From the segregation in $\mathrm{F}_{3}$ it was possible to select families expected to give the critical 1 - and 2 -gene segregations in $\mathrm{F}_{4}$. The results, summarized in table 11, indicate no unexpected interactions between the $C c, R r$, and $P p$ gene pairs.

A number of other $\mathrm{F}_{4}$ progenies were grown to test for possible interactions of the $S s$ gene pair with each of the pigmentation genes. Three families judged from their mottling pattern to be $S S$ or $s s$ and six families judged to be $S s$ were grown within each of the red, dark-red, purple, and black seed-coat color classes. Self-colored parents and parents with restricted mottling bred true in every case. Parents with diffuse mottling in every case produced progeny with restricted mottling, diffuse mottling, and self-colored seed coats in ratios of approximately $1: 2: 1$. The results showed that the effect of the primary pigmentation genes was largely confined to determining the color of the mottled portions of the seed coat. The single exception involved the $C \_R \_P \_S \_$genotype (black/buff or black/buff). The background color accompanying black mottling was almost invariably slightly but distinctly different from the background color of plants with dark red, purple, or red mottling. According to the Munsell color system, this modification was usually from approximately 7.5YR 8/4 for nonblack mottled plants to approximately 7.5YR $7 / 4$ for black mottled plants. 


\section{Additional Hybrids of Red $\times$ Buff Background Color}

The discovery that cooperative action of the $C R P$ pigmentation alleles affects not only the color of the mottled portions of the seed coat but also

TABLE 11

OBSERVED SEGREGATION AND GOODNESS OF FIT TO VARIOUS MONOGENIC AND DIGENIC RATIOS WITHIN F 4 FAMILIES DERIVED FROM

$F_{3}$ FAMILIES OF KNOWN GENOTYPE IN THE HYBRID WESTAN $\times$ L48

\begin{tabular}{|c|c|c|c|c|c|c|c|}
\hline $\begin{array}{c}\mathrm{F}_{3} \\
\text { Parent }\end{array}$ & $\underset{\text { Genotype }}{\mathrm{F}_{3}}$ & $F_{4}$ Segregation & $\underset{\text { Genotype }}{\mathrm{F}_{4}}$ & $\begin{array}{c}\text { Observed } \\
\text { number }\end{array}$ & $\begin{array}{l}\text { Expected } \\
\text { number }\end{array}$ & $x^{2}$ & $\underset{\text { exceeds }}{\mathbf{P}}$ \\
\hline $\begin{array}{r}\text { Dark red } \\
\text {. }\end{array}$ & CCRrppss & $\begin{array}{l}\text { Homo. dark red. } \ldots \ldots \ldots \\
3 \text { dark red : } 1 \text { red. } \ldots \ldots \ldots\end{array}$ & $\begin{array}{l}\text { CCRRppss } \\
\text { CCRrppss }\end{array}$ & $\begin{array}{r}2 \\
10 \\
12\end{array}$ & $\begin{array}{l}4 \\
8 \\
12\end{array}$ & $\begin{array}{l}1.000 \\
0.500 \\
1.500\end{array}$ & 0.20 \\
\hline Purple & CCrrPpss & $\begin{array}{l}\text { Homo. purple. .......... } \\
3 \text { purple : } 1 \text { red........ }\end{array}$ & $\begin{array}{l}C C r r P P_{88} \\
C C r r P p s 8\end{array}$ & $\begin{array}{r}4 \\
8 \\
12\end{array}$ & $\begin{array}{r}4 \\
8 \\
12\end{array}$ & $\begin{array}{l}0.000 \\
0.000 \\
0.000\end{array}$ & .99 \\
\hline Black & $C c R R P P s 8$ & $\begin{array}{l}\text { Homo. black ............ } \\
3 \text { black : } 1 \text { white. . . } \ldots\end{array}$ & $\begin{array}{l}C C R R P P_{88} \\
C c R R P P_{88}\end{array}$ & $\begin{array}{r}3 \\
9 \\
12\end{array}$ & $\begin{array}{r}4 \\
8 \\
12\end{array}$ & $\begin{array}{l}0.250 \\
0.125 \\
0.375\end{array}$ & .50 \\
\hline Black/buff & CCRRPpSS & $\begin{array}{l}\text { Homo. black . . . . . . . . . } \\
3 \text { black : } 1 \text { dark red. . } \ldots\end{array}$ & $\begin{array}{l}C C R R P P S S \\
C C R R P p S S\end{array}$ & $\begin{array}{r}3 \\
9 \\
12\end{array}$ & $\begin{array}{r}4 \\
8 \\
12\end{array}$ & $\begin{array}{l}0.250 \\
0.125 \\
0.375\end{array}$ & .50 \\
\hline Black/buff & CCRrPPSS & $\begin{array}{l}\text { Homo. black. . . . . . . . . . } \\
3 \text { black : } 1 \text { purple...... }\end{array}$ & $\begin{array}{l}\text { CCRRPPSS } \\
\text { CCRrPPSS }\end{array}$ & $\begin{array}{r}5 \\
7 \\
12\end{array}$ & $\begin{array}{l}4 \\
8 \\
12\end{array}$ & $\begin{array}{l}0.250 \\
0.125 \\
0.375\end{array}$ & .50 \\
\hline Black & CCRrPpss & $\begin{array}{l}\text { Homo. black. } \ldots \ldots \ldots \ldots \\
3 \text { black : } 1 \text { purple........ } \\
3 \text { black : } 1 \text { dark red..... } \\
3 \text { dark red }: 1 \text { red....... }\end{array}$ & $\begin{array}{l}\text { CCRRPPss } \\
C C R r P P s s \\
C C R R P p s s \\
C C R r P p s s\end{array}$ & $\begin{array}{r}1 \\
6 \\
3 \\
8 \\
18\end{array}$ & $\begin{array}{r}2 \\
4 \\
4 \\
8 \\
18\end{array}$ & $\begin{array}{l}0.500 \\
1.000 \\
0.500 \\
0.000 \\
2.000\end{array}$ & .50 \\
\hline Black/buff & $C C R r P p S S$ & 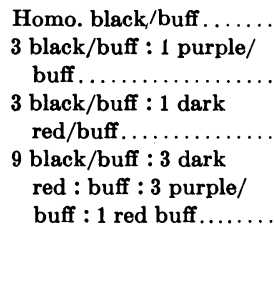 & $\begin{array}{l}\text { CCRRPPSS } \\
\text { CCRrPPSS } \\
\text { CCRRPpSS } \\
\text { CCRrPpSS }\end{array}$ & $\begin{array}{c}1 \\
4 \\
2 \\
11 \\
18\end{array}$ & $\begin{array}{l}2 \\
4 \\
4\end{array}$ & $\begin{array}{l}0.500 \\
0.000 \\
1.000 \\
1.125 \\
2.625\end{array}$ & 0.30 \\
\hline
\end{tabular}

buff background color raised the question of the effect of these alleles on the red background color produced by srsr. Information bearing on this question was obtained from four hybrid combinations in which $S r_{-}$and srsr occurred in several genetic backgrounds. The $\mathrm{F}_{2}$ segregations observed in these 
hybrids, reported in table 12 , provide further support for the monogenic control of buff vs. red background color. Careful inspection of the seed-coat colors of both $\mathrm{F}_{1}$ and $\mathrm{F}_{2}$ individuals with buff background color confirmed that the changè reported above in the background color accompanies black

TABLE 12

OBSERVED SEGREGATION AND GOODNESS OF FIT TO RATIOS OF $3: 1$ IN THE $\mathrm{F}_{2}$ OF HYBRIDS BETWEEN PARENTS WITH BUFF VS. RED BACKGROUND COLORS

\begin{tabular}{|c|c|c|c|c|c|}
\hline Hybrid & $F_{2}$ Phenotypes & $\begin{array}{c}\text { Observed } \\
\text { number }\end{array}$ & $\begin{array}{l}\text { Calculated } \\
\text { number }\end{array}$ & $x^{2}$ & P exceeds \\
\hline I166-7-1 $\times$ I166-7-2 & $\begin{array}{l}\text { Purple/buff } \ldots \ldots \ldots \ldots \ldots \ldots \ldots \ldots \ldots \ldots \\
\text { Purple/red } \ldots \ldots \ldots \ldots \ldots \ldots \ldots \ldots \ldots \ldots \ldots\end{array}$ & $\begin{array}{r}129 \\
36\end{array}$ & $\begin{array}{r}123.75 \\
41.25\end{array}$ & $\begin{array}{l}0.223 \\
0.668 \\
0.891\end{array}$ & 0.30 \\
\hline $\mathrm{I} 166-7-8 \times \mathrm{L} 122$ & $\begin{array}{l}\text { Black/buff } \ldots \ldots \ldots \ldots \ldots \ldots \ldots \ldots \ldots \ldots \\
\text { Black/red } \ldots \ldots \ldots \ldots \ldots \ldots \ldots \ldots \ldots \ldots \ldots\end{array}$ & $\begin{array}{r}170 \\
54\end{array}$ & $\begin{array}{r}168 \\
56\end{array}$ & $\begin{array}{l}0.024 \\
0.071 \\
0.095\end{array}$ & 0.70 \\
\hline $\mathrm{I} 166-7-1 \times \mathrm{L} 122$ & $\begin{array}{l}\text { Black or purple/buff } \ldots \ldots \ldots \ldots \ldots \ldots \ldots \\
\text { Black or purple/red............. }\end{array}$ & $\begin{array}{r}165 \\
46\end{array}$ & $\begin{array}{r}158.25 \\
52.75\end{array}$ & $\begin{array}{r}0.288 \\
0.864 \\
1.152\end{array}$ & 0.20 \\
\hline I166-7-3 $\times$ L122 & $\begin{array}{l}\text { Black or dark-red/buff } \ldots \ldots \ldots \ldots \ldots \ldots \\
\text { Black or dark-red/red } \ldots \ldots \ldots \ldots \ldots \ldots\end{array}$ & $\begin{array}{r}132 \\
49\end{array}$ & $\begin{array}{r}135.75 \\
45.25\end{array}$ & $\begin{array}{l}0.103 \\
0.310 \\
0.413\end{array}$ & 0.50 \\
\hline
\end{tabular}

mottling. It also revealed no consistent differences in the red background color of individuals genotypically $C \_r r p p S_{-}, C \_R \_p p S_{-}$, or $C \_r r P \_S \_$; however, the red background color of $C \_R \_P \_S \_$individuals was definitely more purplish in hue. Although some variations in color existed among all genotypes, presumably as a result of the segregation of minor modifying genes, the usual background colors of the black mottled and nonblack mottled genotypes were, on the Munsell system, 10.0RP 4/6 and 2.5R 4/6, respectively. 


\section{LITERATURE CITED}

AlLARD, R. W.

1952. The inheritance of hypocotyl color in lima beans. Proc. Amer. Soc. Hort. Sci. 60 : 387-90.

RHIND, D. A.

1933. A note on the inheritance of seed-coat color in Phaseolus lunatus L. Ind. Jour. Agr. Sci. 3:360-64. 

The journal Hilgardia is published at irregular intervals, in volumes of about 600 pages. The number of issues per volume varies.

Subscriptions are not sold. The periodical is sent as published only to libraries, or to institutions in foreign countries having publications to offer in exchange.

You may obtain a single copy of any issue free, as long as the supply lasts; please request by volume and issue number from:

\section{Publications Office \\ College of Agriculture \\ Berkeley 4, California}

The limit to nonresidents of California is 10 separate issues on a single order. A list of the issues still available will be sent on request. 